\title{
Jordan's Principle, governments' paralysis
}

$\mathrm{C}$ hildren are vulnerable members of our society. They are voiceless in decision-making, subject to the judgments and actions of others. First Nations people are also vulnerable - victims of ill-will and broken promises and suffering from the worst social, economic and health conditions in Canada.

So imagine the unenviable situation to be a First Nations child, very sick and living on a reserve where there are minimal children's services.

"Jordan" was a child with a rare neuromuscular disorder born in 1999 on the Norway House Cree Nation reserve in northern Manitoba. ${ }^{1}$ His complex medical needs could not be managed there, so he was referred for treatment to Winnipeg. As his illness progressed, he became wheelchair-bound, ventilator dependent and unable to speak.

By 200I, Jordan's hospital caregivers decided to discharge him to specialized foster home care near to his home reserve. Both his physicians and family agreed that this decision was best for Jordan. Then, the bureaucrats ruined it. The federal and Manitoba governments could not agree on who was financially responsible for Jordan's care. Bickering erupted: over foster care, transportation to clinic - even over tiny items, like a showerhead. For over 2 years, warring bureaucrats left no stone unthrown.

This intergovernmental dispute only stopped when - you guessed it - Jordan died from his underlying disease in a Winnipeg hospital, far from his family and community. No one has been held accountable for blocking Jordan's care closer to home.

Canada is a party to the I989 United Nations Convention on the Rights of the Child, a treaty that states: "In all actions concerning children, whether undertaken by public or private social welfare institutions, courts of law, administrative authorities or legislative bodies, the best interests of the child shall be a primary consideration."2

Jordan's interests fell a distant second; intergovernmental squabbling over the duty to pay came first. Canada contravened this treaty.

Canada's Charter of Rights and Freedoms forbids discrimination. Many of the services Jordan needed would be paid for without question for a white Manitoban, or off-reserve Aboriginal resident. It was Jordan's living on-reserve that caused the bureaucracy to choke. That is discrimination pure and simple.

Canada's constitution recognizes and affirms Aboriginal and treaty rights. The Supreme Court in I 884 declared "the Government has the responsibility to act in a fiduciary capacity with respect to aboriginal peoples," in a relationship that "is trust-like, rather than adversarial." One wonders how this obligation was met by the bureaucrats who allowed Jordan to live and then die in the Winnipeg hospital far from his loved ones, while the adversarial turf war raged.

Other First Nations children with complex medical needs are frequently caught in this bureaucratic nightmare. Last
March, the families of 37 profoundly disabled Norway House Cree Nation children were told that funds for further health professional and support services in their community would cease. ${ }^{3}$ Families wanting health care for their children were forced to send them away - likely forever.

Those who defend the status quo say that Canada's geography makes health care delivery for complex chronic illness difficult and costly. The same critics usually omit to mention that Canada's geography - its petroleum, timber, minerals and waterways, much of it within First Nations' traditional territory - also makes it wealthy. Geography is no excuse for the pusillanimous, inequitable distribution of wealth, such that advanced care exists only in the south and First Nations children, parents and communities endure psychological and cultural stress to access it. The point isn't what portion of the cost the federal, territorial and provincial governments each pay but, rather, that the wrangling stop so that the right care, at the right place, at the right times can be provided for people on First Nations' reserves.

Today the CMAJ endorses what is called "Jordan's Principle" (www.fncfcs.com/more/jordansPrinciple.php). Consistent with the Convention on the Rights of the Child, we endorse putting the medical needs of First Nations' children first. We also make this recommendation: that if the provincial, territorial and federal governments ignore Jordan's Principle and entangle themselves in financial or jurisdictional battles first, then governments deserve to be sued, in the most winnable test case that First Nations' advocates can manage. Let the courts decide, if the bureaucrats and politicians continue to refuse to find a timely resolution.

\section{Noni MacDonald MD MSc \\ Section Editor, Public Health, CMAJ \\ Amir Attaran LLB PhD \\ Canada Research Chair in Law, Population Health and \\ Global Development Policy \\ University of Ottawa, Ottawa, Ont. \\ For the Editorial-Writing Team (Paul C. Hébert, Matthew Stanbrook, Barbara Sibbald and Ken Flegel)}

Acknowledgements: We acknowledge the contributions to this editorial of Cindy Blackstock MM, Executive Director, First Nations Child and Family Caring Society of Canada, Ottawa; Bradford W. Morse LLM, Professor of Law, University of Ottawa; and Jeff Reading PhD PHS, Scientific Director, CIHR Institute for Aboriginal Peoples' Health, University of Victoria, Victoria.

\section{REFERENCES}

I. Lavallee TL. Honouring Jordan: Putting First Nations children first and funding fights second. J Paediatr Child Health 2005;10:527-9.

2. United Nations Convention on the Rights of the Child. Available: www.ohchr.org /english/law/pdf/crc.pdf (accessed 2007 Jul 9).

3. Assembly of Manitoba Chiefs. Disabled children lose services because governments won't pay. Available: www.manitobachiefs.com/press/norway-house.pdf (accessed 2007 June I8). 